\title{
Asian currency crisis and European growth prospects
}

by Professor J H Dalhuisen

\author{
Professor Dalhuisen considers the possible effects within the Western banking system of \\ the current crises in the banking sector in Asia.
}

$\mathrm{T}$ he crisis we see today in Asia is in essence nothing more than an old-fashioned 'boom and bust' characterised by over-confidence in growth prospects, leading to an excessive increase in manufacturing capacity and inflow of funds in other assets, especially real estate. Some may say that the reasons are more profound, but I don't think so. As usual, most of the financing was short-term, in large part foreign funds. Such financing is, in times of prosperity, easy to attract at competitive interest rates when lenders take an increasingly rosy view of risk. This can go on for a long time, in fact, as long as lenders are willing to roll over their loans and provide more funds. But eventually, saturation becomes unavoidable when local demand cannot be increased, export is hindered by high exchange rates caused by the same large inflow of foreign funds, also by improperly thought out projects and insufficient upgrading of the product range. Devaluation and longer-term product refinement and rethinking must follow, but take time to work through the system, as they are not likely instantly to take care of all excess or useless capacity (in the process of being) created. Asset deflation in plant and land, the price of which is likely first to have been inflated, is the result. Bankruptcies loom, banks are squeezed, confidence evaporates and something has to give.

\section{INDICATIONS OF CRISIS}

Normally, the first signs are difficulty in servicing debt, particularly foreign debt, followed by a liquidity crisis, the sudden end to building sprees, sharp rises in unemployment and a stock exchange and land price collapse. Subsequently, the concern will be that governments may be asked, expected, tempted or forced to take the lead and try to spend themselves out of the problems. Deflation is then likely to be followed by inflationary fears. In this environment the currency will not only devalue, but also crash, even reaching irrational lows, especially in countries with political problems too, as is currently the case in South Korea and, particularly, Indonesia. If these adjustments happen quickly governments are apt to blame them on the nebulous army of speculators, but if the latter even do exist, they only take advantage of bad policies and do not create them. The accusations in this connection usually come from those who believe that government policies should be sacrosanct and not subject to the ordinary laws of economics, or are reminded of their existence. Often, however, it is not the professional speculator.

Heavy swings in values may simply happen because there is no depth left in the markets; a few local orders to sell shares or the local currency add disproportionately to the upheaval. The alternative is years of adjustment and there may therefore be advantages in bubbles being burst in this way. The sharp, sudden shock concentrates the mind. Big devaluations quickly export some of the pain to others as the hope is for an export-led recovery. Yet this may also aggravate the problems elsewhere in the region. Another danger is that banks, if seriously mismatched between the currencies of their assets and liabilities, as in the present case, will be squeezed further and a whole banking crisis is then likely to develop. In such cases, the pressure on governments for bail-outs will naturally intensify.

This is where we are today in the Tiger economies and the scenario is, I think, mostly the same, although several commentators have pointed out the considerable differences between the various countries. It does not in my view greatly alter the patterns of cause and effect or the trigger: the loss of confidence started by a sudden realisation of excessive refinancing needs, leading to instant liquidity and banking problems, in the present case aggravated by mountains of shortterm foreign debt. So the patient is ill but we know more or less what the disease is. The situation is certainly not unique and there is some comfort in that. In fact the consolation may well be that it has all been seen before. Perhaps people were so little on their guard exactly because they knew it would happen again. It may have been one of the reasons for the complacency of those who were supposed to know better, including the rating agencies. The virtual certainty that international help would subsequently become available may also have encouraged politicians and even central bankers to care less and pursue their growth policies in unsustainable irrational ways. The complacency that may be so engendered has led to a call for more IMF restraint (see George Shulpz, William Simon and Walter Wriston, 'Who needs the IMF?', Wall Street Journal (Europe), 4 February 1998).

\section{CRITICISM OF THE IMF}

Indeed, in the present crisis, G-7 promptly threw an international lifeline through the IMF. It is aimed at restoring confidence as soon as possible to re-establish the return of foreign funds - hopefully at longer maturities and at reasonable cost. In the meantime, the IMF is criticised for being too severe in its monetary and fiscal policy demands, and in its quest for liberalising trade and capital flows, for insisting on opening up the financial sector, especially in Korea, and for demanding western style principles to apply to shareholder protection. Several commentators have criticised this approach I am not sure they are right - quite apart from the fact that it is unwise to argue with your doctor when you are half-dead.

The IMF's aim is to promote sound economic principle, end Mickey Mouse capitalism and make governments give up their 
unrealistic industrial pet projects. The IMF demands, therefore, greater discipline all round. This must be right, certainly for the moment in a situation where it is extremely tempting to loosen the monetary and fiscal policy, more than the present deflation tendencies should allow, in order to favour an inside crowd. Some see it as an American-inspired, unsubtle attempt to inhibit the Asian way of developing their societies and their growth policies, but they cannot prevail where, at the same time, the benefits of open markets are demanded. For these reasons it was, in my view, most unfortunate to start arguing about these terms or to nibble at them, as the Indonesian example has more than shown. The possibility of major government bail-outs, higher inflation and the continuation of governmental involvement in bank and industrial management, simply had to be curtailed through the IMF conditions. Yet because of these arguments, certainly also fuelled in the western press - perhaps the Keynesian inheritance - precious time has now been lost and, at this crucial moment, problems have been allowed to fester.

The unavoidable result has been the continuation of uncertainty, followed by further stock market and currency erosion, which had both already gone too far. The other serious consequence is greater refinancing costs for the countries concerned. Where the IMF is no bank of last resort, this refinancing is crucial and should follow promptly, but increasing costs will cause hesitation and further delay on the part of the affected governments. Some rescheduling and write-off will become necessary, but it should be limited so as not to undermine the credit standing of these countries further; restructuring is the next step. There is some time available as most companies, and even banks, will still be able to cover their current operating costs; governments protect deposits and few will be legally bankrupt, but this situation will not continue for ever and time is of the essence. The aim of the restructuring should be twofold: irrelevant and costly activities must be shed and lenders must be turned into shareholders or face losing much of their investment. No distinction should be made here between local and foreign investors. In such a scenario there should be no need for a general bail-out at all. I understand that local insolvency laws have no way of achieving this conversion promptly; in any event problematic in respect of secured creditors, even in countries that have more up-to-date laws in this respect. It is also clear that foreign banks will try to claim an exceptional position and as their re-financing help is crucial, they are in a strong position, but I wonder whether it is really in their own best interest to push too much, especially where their refinancing will not come cheap.

\section{WHAT EFFECT IN ASIA?}

Even if this can all be sorted out within a reasonable time frame, I think the effect will still be profound in Asia, although not permanent. The key is to prevent long-term stagnation, but also repeats; one would hope that over a two-year period much could be done. It may be that by portraying the IMF and the West as the baddies, the adjustment and re-structuring medicine can be taken quicker. The fact that India, Pakistan, the Philippines, Singapore and Taiwan have not so far become much involved suggests that the crisis is localised and I doubt, therefore, whether its impact need be significant elsewhere in the world, as long as Japan and China are not seriously affected - I would agree that China is perhaps the key, with Hong Kong as an insecure backdoor. China and Japan would in any event have to be the first in absorbing more imports from the countries concerned. In the West, the crisis could be some antidote against remaining inflationary pressures, although the burden would be very unevenly spread and fall first on the export industries. Competitive devaluations between the US, Japan and the EMU are possible in this connection and would not help. I am still optimistic that the worst, that is long years of stagnation or repeated busts, can be avoided for South-East Asia and a serious slow-down everywhere else. The expectation must be that the Tiger economies will re-establish themselves fairly quickly, but a more balanced future growth scenario must be established, while openness and transparency is a condition for it. Longer stagnation is by no means impossible, not even in a disciplined, hardworking and high saving environment, as in Japan. This being said, the Japanese situation is of course very different, because of its lack of foreign debt and its huge reserves.

Although we have also seen very large asset deflation in shares and real estate in Japan, first pushed up by excess liquidity, it has so far not fatally affected the economy as a whole but has only led to more subdued or zero growth. The Yen at first even continued to rise dramatically and is only now weakening. In the meantime, the Japanese foreign surpluses continue unabated. It gives Japan more room to manoeuvre and allows it the luxury to indulge in its natural tendency not to do anything - not always bad if the alternative is unclear. It will, on the whole, only act when it is forced, internally or externally, to do so and even then will only deal with those problems it can clearly see and define and pretend that all others do not exist. It will in any event not show any urgency. It is clear, however, that something will have to be done about its banks where we now see the depth of the problems.

Consolidation, with an elimination of spare capacity seems to me the answer, rather than a wholesale bail-out that will inspire no confidence. It is surprising that it has not already happened and that the government must now use the deregulation weapon to bring it about. The banks should also be cut loose from their groups and the cross-holdings should cease. The IMF might usefully organise the buying out of these holdings as the Financial Times suggests. I am not sure whether more government stimulation of the economy is the answer, or even if it is likely to be successful. Many are crying out for it, but it might only create further savings and saddle the government with considerable future problems where fiscal policy is already out of balance. In any event, the other Asian countries do not have these choices and cannot to the same extent indulge, and this is in a sense a good thing. The remedy may be severe for them but the pain is likely to be shorter.

\section{CAUSES OF BANKING CRISES}

There is similarity between Japan and the Tiger economies insofar as the instability of the banks poses its own threat and has not been confined to Asia. We have seen major banking crises in other parts of the world in the last 25 years, not only in developing countries, such as in South America after 1982, but more recently in the former Soviet Union and Eastern Europe. Many will remember the problems in the USA and Scandinavia, or the enormous write-offs in banking in France and even in Switzerland last year. In fact, the scale of banking problems in the last generation has been breathtaking, and is certainly not less than that in the 1930's. In my view there is ample evidence 
that the inherent instability of banks has become an economic hazard in its own right and that the modern banking system itself is a major source of instability. Moreover, once there is an economic crisis, their involvement tends to make matters worse. Why should that be so and what can or should be done about it? This is the subject about which I should like to say a little more.

\section{Bad management or bad supervision?}

Banking crises are often said to be caused by bad management or bad supervision. That is unlikely to be the whole truth. Bad management is not necessarily the same as bad management decisions, to which good management is not immune; and supervision is not here to run a bank, only to check that the management is reasonably capable and honest, that proper systems are in place and capital adequacy rules are respected. No more can be expected unless banking supervisors want to run the whole system, which basically comes down to the nationalisation of the banking industry, a step no-one proposes any longer. Therefore, it must be left to management as to what to do within their capital ratios with the information provided by proper systems, and it is for that management to decide what risk to take. Bad management is likely to make more mistakes than good management, but neither they nor regulators can guard against outside changes such as deterioration in economic conditions with loans turning bad in economic down-turns and asset deflation affecting their security. Naturally, when a whole economic system changes, as we have seen in Eastern Europe, loans may become non-performing on a massive scale for reasons that have also nothing to do with management or supervision. The restructuring in such situations is an art of its own, a problem which China is now faced with.

\section{Government pressure}

It is therefore by no means always bad management or poor supervision that is the cause of banking crises. It was, I think, not the true problem in the present situation, although some would say that it" was. The problem was rather that there was constant governmental pressure on bank management to ease credit to industry which had little access to capital markets and borrow where possible, home savings alone not being sufficient or cheap enough. In the meantime foreign banks were often pressured, by their own governments, to be aggressive and join in; such was the case in Germany. Government meddling is the bane of a nationalised banking system but it can also happen easily in a decentralised system, as can often be seen in developing countries. This is one problem and was, in the present circumstances, a key element. Moreover, there is a nasty habit in banking to follow the leader - a lemming instinct that easily leads to bad decisions. Banks may be subject to other adverse influences, e.g. from leading shareholders in industrial groups. It is easy to say that this shows at least weak management but no bank management can ignore the environment in which it must operate. The result is always more risk. Another most destabilising factor is in the basket of services that banks deliver, like deposit-taking, payment systems, investment banking services (including advice, underwriting and trading), investment management, and not forgetting their own treasury activity, which not seldom amounts to an in-house hedge fund. These activities are often cross-subsidised and the conglomerisation inherent in modern banking makes the good parts subject to the bad. Thus problems in one particular business may easily bring down the rest and have an instant outside effect.
It is all especially dangerous because of the wafer-thin capital requirements ( $8 \%$ of risk capital) which, in any event, do not allow for important market and business (mismatch) risks and are only meaningful against the background of inherent governmental guarantees. It is true of course that since 1995 the Bank for International Settlements has proposed a selfassessment system for market risk, based on the 'value at risk' approach, accepting banks' own sensitivity studies; but the capital required would not need to be more than three times the theoretical loss. Again, such an approach is only meaningful in the context of a government (or central bank) guarantee. This creates the problem of irresponsibility or moral hazard; this is well-known so I do not need to elaborate. But governments can seldom live up to these guarantees in full banking crises, never mind how much they have interfered before and how much their implicit guarantee was their excuse for doing so, and the bank management's excuse to accept this interference.

The result is that the required capital in situations when it truly matters will always be insufficient for the type of banks we have. That is the same as saying that modern banks inherently take too much risk, are structurally unstable and can never be safe in times of crisis. But there is more: when all goes well, low capital requirements allow banking services and especially credit to be cheap, an attractive proposition so it seems, but it also enables banks to start and fuel asset inflation spirals, especially stock exchange and land price booms. When the crunch comes they may, on the other hand, first start the liquidity squeeze and initiate the asset deflation. Thus banks with their present capital structure are not only inherently unstable - they also tend to aggravate inflation and deflation. The only thing one can say is that it has always been like this, but the question is, should it continue?

\section{IS 'NARROW BANKING' PREFERABLE?}

Should we not look more seriously at narrow banking as a better future model? (see also Martin Wolf, Financial Times, 6 January 1998). The key is that it does not allow consumer deposits that need extra protection and the payment systems, to be run exclusively by banks in the present manner, therefore as part of their overall business. There is much to be said for separate money market funds with limited investment possibilities to be created for consumer depositors, and for the important payment systems to be split out of present banking activity. The latter to operate under central bank guidance. It is in any event improper that problems elsewhere in a bank should affect the basic consumer deposit and payment facilities. Under Glass-Steagall in the US we were of course used to other divisions (see Amicus Curiae, Issue 4, at p. 29); they proved in the end untenable, ineffective and probably even unnecessary. The split resulting from narrow banking is more fundamental and should at least take care of small depositors and systemic risk through the payment system.

Most importantly in the present context, the rest of banking should essentially be free and unsupervised. That would force these broad banks into normal commercial standards of behaviour and it should become clear to all that they do not operate as semi-public institutions. Moral hazards would disappear and, like in any other private business, undue government pressures would have to be resisted. There would not be an $8 \%$ capital adequacy standard. It should rise to $20 \%$ or higher, depending on what risk these financial conglomerates 
wish to take; and what (large) depositors, other clients and credit agencies would think necessary if such institutions wanted to continue deposit-taking, public borrowing, underwriting, market-making and treasury functions - the latter often constituting in-house hedge funds. The argument heard against this is often that, in the case of a full blown banking crisis, governments would still be required to save these institutions, but the higher capital needs would create a better inherent protection and bankruptcy of these institutions should not create greater hazards than that of any other companies of similar size. Higher capital requirements might even be imposed, although this would suck us back into all kind of regulation. In a more efficient world this should be avoided. Banking services would become more expensive, although stiff banking competition and open banking markets would help; so would more direct access of companies to capital markets. It means that the cost of the system is borne by customers rather than by taxpayers.

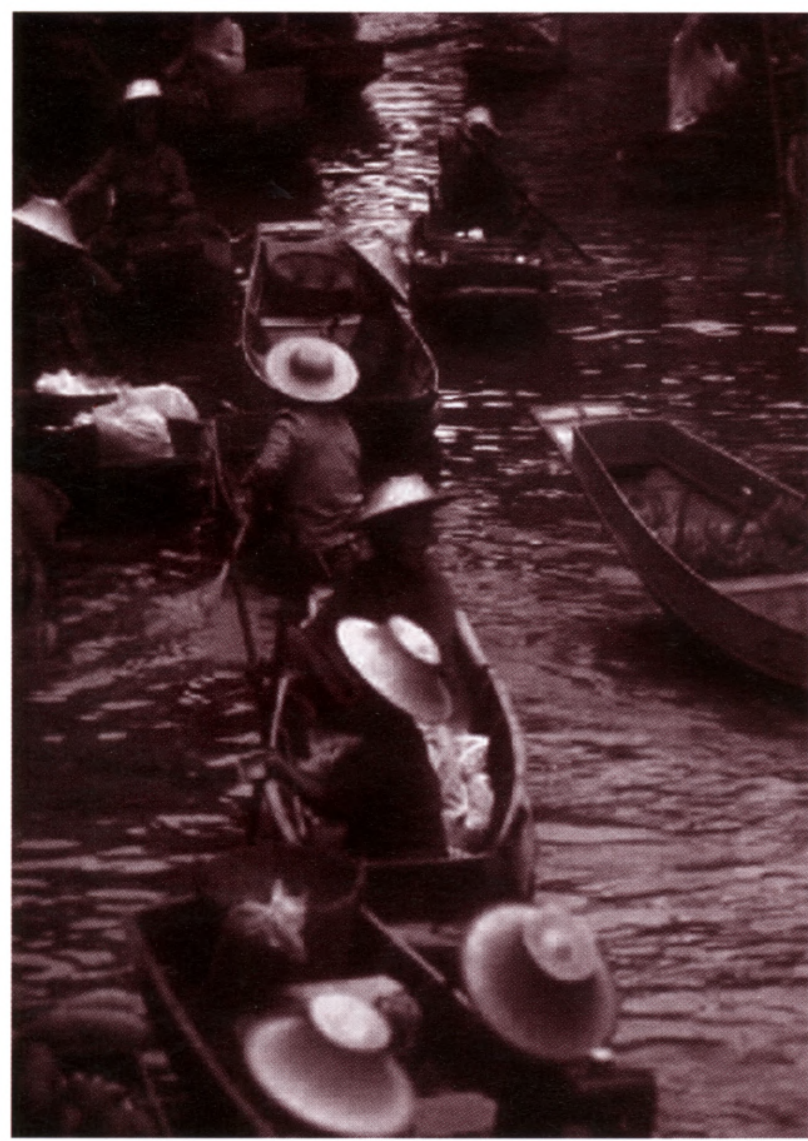

We will have to think about this in any event when banks consolidate further into maybe ten worldwide banks. Who would the bank of last resort of such monsters be, and who would save them in times of crises? How can they properly be regulated with regard to all their local operations? In the meantime most 'investment banks' are indeed no longer banks proper or institutions supervised by bank regulators. They are supervised by security regulators but it is a much lighter supervision and, except for the protection of small investors and the avoidance of market manipulation and insider dealing, one may well ask whether even that supervision proved to be at all necessary, useful or effective. In any event, these institutions, however subject to regulatory capital requirements, will be more normally capitalised, as any large industry is. In this vein, governments have never found it necessary to prescribe capital for the oil industry or the pharmaceutical business, or any others. It may be remembered that the operations of investment banks and security houses were completely overlooked in the original EU approach to liberalising the financial services. They do not pose the same risks and a special regime for them only came in later.

In a system of broader banking that would be capitalised according to normal standards, bank survival chances would be much enhanced and systemic risk reduced. The idea is by no means new, but one wonders what more it takes to get movement on this front. It seems to me that the uncertainties about the nature of modern banks, their special position and related privileges, and whether in truth they operate in the public or private sphere, need to be cleared up. One must admit that the trend seems rather the other way. In the US mortgage banks, as narrow banks, were allowed to broaden out to full banking. The subsequent bankruptcies required a bail-out through tax money of a little less than US $\$ 100$ billion. In Asia we have now seen banks as conduits for excess liquidity, no doubt within their regulatory capital adequacy requirements, get into deep trouble because of serious refunding problems and mismatches between assets and liabilities, leading to a liquidity squeeze upsetting the whole economy.

\section{REDUCING DEPENDENCE ON BANKS}

However managed or supervised, it seems to me that we should not be so dependent on banks and their behaviour; I think it doubtful whether modern economies really need such a system of recycling funds and providing random liquidity. The result only seems to be disaster. It leads me to repeat my longheld view that barking as we know it today, rather than being further pampered, should be forbidden. It is a dangerous business that I don't believe can be effectively contained by regulation. It can only be contained by sound economic principle. Regulation distorts here and provides, in its capital requirements, an appearance of safety that in the end only seem to cover the flank of regulators but protects no one else.

How do we get to such a system? The central banks in G-10 will have to take the lead and split out first payment systems and, subsequently, consumer deposit business. Thereafter they should ask themselves what to do with the rest. Deregulation should then get its chance. Or, to put it differently: while we now ask the Tiger economies to accept normal economic standards and principles of behaviour we should maybe also ask this from our own banks.

\section{Professor J H Dalhuisen}

King's College London and University of Utrecht

The text is from a presentation given in Brussels, to the European Institute of Asian Studies, on 20 January 1998. This article was originally published in the November/December issue of European Business Law Review. 